\section{Antibacterial activities of serum from the Komodo Dragon (Varanus komodoensis)}

\author{
Mark Merchant, ${ }^{1}$ Danyell Henry, ${ }^{1}$ \\ Rodolfo Falconi, ${ }^{1}$ Becky Muscher, ${ }^{2}$ \\ Judith Bryja ${ }^{3}$ \\ 1'Department of Chemistry, McNeese \\ State University, Lake Charles, LA; \\ ${ }^{2}$ Department of Herpetology, San \\ Antonio Zoo, TX; ${ }^{3}$ Department of \\ Herpetology, Houston Zoo, TX, USA
}

\section{Abstract}

Komodo dragons (Varanus komodoensis) are able to feed on large prey items by injecting a dose of toxic bacteria with their bite that, over time, kills the prey by systemic infection. Dragons also suffer bites from other members of their own species during territorial disputes and feeding frenzies. However, they do not suffer the same fate as their prey, suggesting that they have developed a strong immunity to bacterial infections. This study was undertaken to determine the antibacterial activities of serum from the Komodo dragon. Bacterial cultures were treated with different volumes serum from Varanus komodoensis and the growth was monitored by optical density at $430 \mathrm{~nm}$. In addition, the serum was treated with protease, chelators of divalent metal ions, or with mild heat to determine the mechanism of antibacterial activities. Treatment of bacterial cultures with serum from Komodo dragons (Varanus komodoensis) resulted in a volumedependent decrease in bacterial growth. Cultures of Escherichia coli, Staphylococcus aureus, and Klebsiella oxytoca exhibited moderate-strong growth inhibition by $V$. komodoensis serum, while cultures of Streptococcus epidermitis, Salmonella typhimurium, Providencia stuartii, and Shigella flexneri were nearly completely obliterated for $24 \mathrm{~h}$ by only $10 \%$ $(\mathrm{v} / \mathrm{v})$ serum. The antibacterial activity of $V$. komodensis serum occurred very rapidly, as $18 \%$ of $E$. coli growth was inhibited by a five min exposure to serum. Furthermore, 10 - and 20-min incubations of $E$. coli with serum from $V$. komodoensis resulted in 43 and $68 \%$ inhibition of bacterial growth, respectively. The bactericidal capacity of the serum against $E$. coli was 2,075,000 bacteria/ $\mu \mathrm{L}$ serum, and was inhibited by mild heat treatment, pronase, EDTA, and phosphate, indicating that the antibacterial action is most probably due to the presence of a potent serum complement protein system.

\section{Introduction}

The Komodo dragon (Varanus komodoensis) is an endangered species of monitor lizard indigenous to only five islands in the Lesser Sunda region of southeast Indonesia. ${ }^{1}$ It is the largest lizard in the world, reaching lengths of more than 3 meters. ${ }^{2}$ These reptiles primarily inhabit the tropical savannahs, and their boundary woodlands, of these islands. They feed as both scavenger and predators, ${ }^{3}$ eating a broad spectrum of food items.

Komodo dragons kill prey items with a lethal bite that is believed to inject toxic bacteria into the blood stream of these animals. ${ }^{4-5}$ However, recent studies have shown that Komodo dragon saliva also contains a potent and complex venom, which causes anticoagulation and induction of systemic shock in prey animals. ${ }^{6}$ After days, or even weeks, depending on the size of the prey and the number of bites, the prey succumbs to the lethal effects of systemic infection or shock. However, despite the fact that Komodo dragons fight and inflict bites on each other, ${ }^{2}$ these lizards are not known to be affected by septic infections. This would seem to indicate that these animals have developed some type of immune mechanism(s) that protect against potential sepsis due to bites from other Komodo dragons.

Despite the endangered status of the Komodo dragon, practically nothing is known about the immune systems of these threatened reptilians. Knowledge of the immune system will be of interest to both evolutionary biologists and conservationists of these reptilians. The primary goal of this project was to characterize the antibacterial properties of serum from the Komodo dragon.

\section{Materials and Methods}

\section{Chemicals and biochemicals}

Nutrient broth and low EEO agarose were purchased from Intermountain Scientific (Kaysville, UT). Bacterial cultures (American Type Culture Collection) were purchased from Remel (Lenexa, KS). The following species were used for representatives of Gram- negative species: Escherichia coliform (ATCC 25922), Shigella flexnerii (ATCC 700930), and Klebsiella oxytoca (ATCC 49131), Salmonella typhimurium (ATCC 14028), Providencia stuartii (33672) and the following Gram- positive species: Staphylococcus aureus (ATCC 6538), and Streptococcus epidermitis (ATCC 19615). Pronase from Streptomyces griseus was purchased from Sigma Chemical Company (St. Louis, M0).
Correspondence: Mark Merchant, DEof Biochemistry, McNeese State University Lake Charles, LA 70609, USA. Tel. + 1.337.4755773 E-mail: mmerchant@mcneese.edu

Key words: innate immunity, lizard, reptile, serum complement, varanid.

Acknowledgements: the authors wish to acknowledge the help of San Antonio Zoo employees: J. Stephen McCusker (Director), Alan Kardon (Curator of Herpetology and Aquarium), and Rob Coke and Jenny Nollman (Veterinarians), and Houston Zoo employees Rick Barongi (Director), Stan Mays (Director of Herpetology), and Maryanne Tocidlowski (Veterinarian), for permission to work with zoo animals and collection of samples. In addition, we also thank technicians Courtney Threadgill, Candice Robinson, and Herpetology/Aquarium staff (San Antonio Zoo) for help in restraining animals during blood collection.

Contributions: MM, provided grant funding, designed the experiments for the study, conducted some of the laboratory work, wrote the majority of the manuscript; DHRF conducted the majority of the laboratory work, wrote portions of the manuscript; BM, JB, conceived of the general idea of the study, coordinated the collection of samples, made small contributions to the development of the manuscript.

Funding: this research was funded by a McNeese State University Alumni Association Faculty Development Award. In addition, support was provided by a NSF Research Commercialization/ Educational Enhancement Plan grant administered by the Louisiana Board of Regents.

Conflict of interests: the authors declare no potential conflict of interests.

Received for publication: 30 August 2011.

Revision received: 14 August 2012.

Accepted for publication: 29 August 2012.

This work is licensed under a Creative Commons Attribution NonCommercial 3.0 License (CC BYNC 3.0).

CC Copyright M. Merchant et al., 2013 Licensee PAGEPress, Italy

Microbiology Research 2013; 4:e4 doi:10.4081/mr.2013.e4

\section{Collection of blood samples}

Blood samples were collected from Komodo dragons at the Houston and San Antonio zoos. Blood was drawn from the tail vein, transferred to Vaccutainer ${ }^{\mathrm{TM}}$ tubes, and allowed to clot for at least five $\mathrm{h}$ at ambient temperature before the serum was collected. The amount of blood collected from each individual depended on the size of the animal, and was at the discretion of 
the attending veterinarian. Blood was collected from three adults $(20-81.5 \mathrm{~kg})$ and five juveniles (1.5-6.2 kg), and the serum was pooled so that average antibacterial values for this species could be generated. The samples were stored at $-20^{\circ} \mathrm{C}$ until used for the antibacterial assays. The collection of blood from these animals was conducted in accordance with the animal care institutional policies of the Houston and San Antonio Zoos.

\section{Serum volume-dependent antibacterial assays}

Two hundred $\mu \mathrm{L}$ samples containing various volumes $(20-200 \mu \mathrm{L})$ of Komodo dragon serum in sterile microtiter plates were inoculated with five $\mu \mathrm{L}$ of bacterial culture from $\log$ phase cultures and incubated for $24 \mathrm{~h}$ at $37^{\circ} \mathrm{C}$. The optical density of each sample was measured at $0,3,612$ and $24 \mathrm{~h}$ using a Biorad Benchmark Plus ${ }^{\mathrm{TM}}$ microtiter plate reader at $430 \mathrm{~nm}$.

\section{Kinetic antibacterial assay}

Five hundred $\mu \mathrm{L}$ of Komodo dragon serum were inoculated with $20 \mu \mathrm{L}$ of an $E$. coli culture in log phase growth. At various time points, 50 $\mu \mathrm{L}$ of a dilution of each sample were spread onto the surface of nutrient broth agar plates to determine the CFUs for each sample. The samples were typically plated at five different dilutions (1:100-1:106, in sterile isotonic saline) to obtain plates with a quantity of colonies such to provide a reasonable estimate of bacterial density (50-400 CFUs per plate). To determine possible mechanisms of antibacterial action, pooled serum from Komodo dragons was incubated with one unit/mL pronase (isolated from Streptomyces griseus), $5 \mathrm{mM}$ EDTA (pH 8.0), or $5 \mathrm{mM}$ phosphate for $30 \mathrm{~min}$ at ambient temperature. In addition, four aliquots of serum were incubated at $56^{\circ} \mathrm{C}$ for $30 \mathrm{~min}$. These serum samples $(500 \mu \mathrm{L})$ were all incubated with $20 \mu \mathrm{L}$ of an $E$. coli culture in $\log$ phase growth. The samples were incubated for $15 \mathrm{~min}$ at ambient temperature, diluted serially (1:100 $\left.-1: 10^{6}\right)$ in sterile saline, and 50 $\mu \mathrm{L}$ of each sample were plated on nutrient agarose as described above.

\section{Statistics and controls}

All assays were conducted in quadruplicate, and the results are expressed as the means \pm standard deviations for four independent replicates. The statistical comparisons between groups were conducted using analyses of variance and Duncan's post-hoc comparisons and $\mathrm{P}<0.05$ was chosen as the standard probability of statistical significance.

\section{Results}

The results in Figure 1 show that serum from $V$. komodoensis inhibits the growth of Gram negative bacteria. The serum inhibited growth of $E$. coli in a volume-dependent manner (Figure 1A). At 24 hrs, 10\% V. komodoensis serum (v/v) produced a $44 \%$ decrease in $E$. coli growth, while $25,50,75$, and $100 \%$ serum caused 58, 75, 93, and 98\% decreases in growth, respectively. By way of comparison, incubation of $10 \% \mathrm{~V}$. komodoensis serum with Klebsiella oxytoca cultures resulted in 34\% growth inhibition at $24 \mathrm{hrs}$, while $25 \%$ serum caused a $65 \%$ decrease in bacterial density (Figure 1B). All serum volumes at, or above, $50 \%$ completely inhibited the growth of $K$. oxytoca cultures at $24 \mathrm{hrs}$. Serum from $V$. komodoensis ( $10 \%$ volume) inhibited Shigella flexnerii growth by $95 \%$ at 24 hrs (Figure 1D), and exhibited similar results for cultures of Salmonella typhimurium (Figure 1E). Cultures of Providencia stuarti growth were completely obliterated (100\%) inhibition by only $10 \%$ serum (Figure 1C).

Figure 2 illustrates the effects of serum from $V$. komodoensis on the growth of Gram positive bacteria. Serum (10\% volume) from $V$. komodoensis inhibited the growth of Staphylococcus aureus by $64 \%$ at $24 \mathrm{hrs}$, while $25,50,75$, and $100 \%$ serum resulted in 68,84 , 94 , and $93 \%$ reduction in growth, respectively (Figure 2A). In contrast, 10\% serum from $V$. komodoensis inhibited the growth of Streptococcus epidermitis cultures by $49 \%$ (Figure 2B).

The bacterial-killing capacity of serum from $V$. komodoensis for $E$. coli is displayed in Figure 3. A $20 \mu \mathrm{L}$ sample of positive control culture of E. coli in log phase growth was found to have $16.4 \pm 0.4$ million viable bacteria. In contrast, the addition of $25 \%(\mathrm{v} / \mathrm{v})$ of serum from $V$. komodoensis to the bacterial growth medium caused a significant decrease $(\mathrm{P}<0.05)$ to $5.2 \pm 2.1$ million CFU. Further increases in serum to $50 \%$ resulted in decreased bacterial viability $(1.3 \pm 0.2$ million $\mathrm{CFU})$. Because only $20 \mu \mathrm{L}$ of the bacterial culture were used for colony determination, we calculated that one $\mu \mathrm{L}$ of serum from $V$. komodoensis has the capacity to kill approximately 2.24 million $E$. coli bacteria.

Figure 4 shows the results of a kinetic analysis of the ability of serum from $V$. komodoensis to inhibit the growth of $E$. coli bacterial cultures. The antibacterial activity occurred quickly, as $18 \%$ of the bacteria (2.95 million) were killed within 5 min of exposure to serum from $V$. komodoensis. Further incubation resulted in $43 \%$ ( 7.05 million) of the bacteria killed at $10 \mathrm{~min}$ of exposure, and the antibacterial action was maximal at $20 \mathrm{~min}$ as $68 \%$ (11.2 million) of the $E$. coli were killed.
The data in Table 1 exhibits the results of a mechanistic study, showing the susceptibility of the antibacterial effects to mild heat treatment and chelators of divalent metal ions. Treatment of $E$. coli cultures with serum from the Komodo dragon results in $96.4 \%$ of the bacteria killed. However, mild heat treatment $\left(56^{\circ} \mathrm{C}, 30 \mathrm{~min}\right)$ of the serum resulted in only 4.0\% antibacterial activity. Likewise, treatment of the serum with $5 \mathrm{mM}$ EDTA or $5 \mathrm{mM}$ phosphate resulted in only $6.3 \%$ or $8.7 \%$ antibacterial activity, respectively.

\section{Discussion}

Eukaryotic organisms must continuously defend themselves against infiltration and colonization by microorganisms. Host defense occurs via complex mechanisms and can be divided into two distinct, but interrelated, types of responses: acquired immunity and innate immunity. Acquired immunity requires prior exposure to a specific antigen before a full immunological assault can be established by the host organism. In addition, the acquired immune response is complex and can often take several days to become fully activated. The innate immune response comprises a significant portion of the immune system and acts as an initial defense mechanism against microbial growth shortly after infection occurs. These innate defense responses are activated shortly after exposure and act to slow or stop an infection in the initial stages so that the acquired immune response can be initiated. Also, the innate immune system functions in the activation of the acquired immune system by generating chemotactic factors and producing cytokines that initiate the development and maturation of specific T-cell and B-cell populations. Anecdotal evidence suggests that Komodo dragons are resistant to microbial

Table 1. Effects of heat treatment, protease treatment, or metal chelators on the antibacterial activity of serum from $V$. komodoensis against $E$. coli. The $E$. coli survival was determined by manual colony counts. The results represent the means of four independent determinations.

\begin{tabular}{lcc} 
Treatment & CFU & $\begin{array}{c}\text { Antibacterial } \\
\text { activity }\end{array}$ \\
None & $12.7 \times 10^{6}$ & - \\
Komodo dragon serum & $0.46 \times 10^{6}$ & $96.4 \%$ \\
\hline Serum, $56^{\circ} \mathrm{C}, 30$ min & $12.2 \times 10^{6}$ & $4.0 \%$ \\
Serum + pronase & $12.4 \times 10^{6}$ & $2.4 \%$ \\
Serum + 5 mM EDTA & $11.9 \times 10^{6}$ & $6.3 \%$ \\
\hline Serum + 5 mM phosphate & $11.6 \times 10^{6}$ & $8.7 \%$ \\
\hline CFU, colony-forming units. & &
\end{tabular}


infections. These animals often sustain serious injuries, including open wounds, due to interspecies fighting in territorial disputes. ${ }^{7}$ Despite the propensity of dragons to resist microbial infection, the mechanisms of immunity are not well-characterized.

Montgomery et $a l .{ }^{4}$ isolated many bacterial species from both captive and wild Komodo dragons, some of which were extremely toxic to mice, particularly Pasteurella multocida, supporting the idea that bite wounds inflicted by Komodo dragons may induce systemic septicemia in their prey. However, it would be reasonable to expect that Komodo dragons would have developed innate immune mechanisms to combat possible infection by the bacteria in their own saliva. In addition, antibodies against $P$. multocida were found in the plasma of the Komodo dragons, ${ }^{4}$ supporting the idea that their immune systems are equipped to deal with the heavy bacteria load present in their saliva. Antibacterial activities of other reptilian species have been assessed, particularly those of several crocodilian species. ${ }^{8,9}$ Merchant et al. ${ }^{8}$ showed that the bactericidal capacity of serum from the American alligator (Alligator mississippiensis) toward $E$. coli was
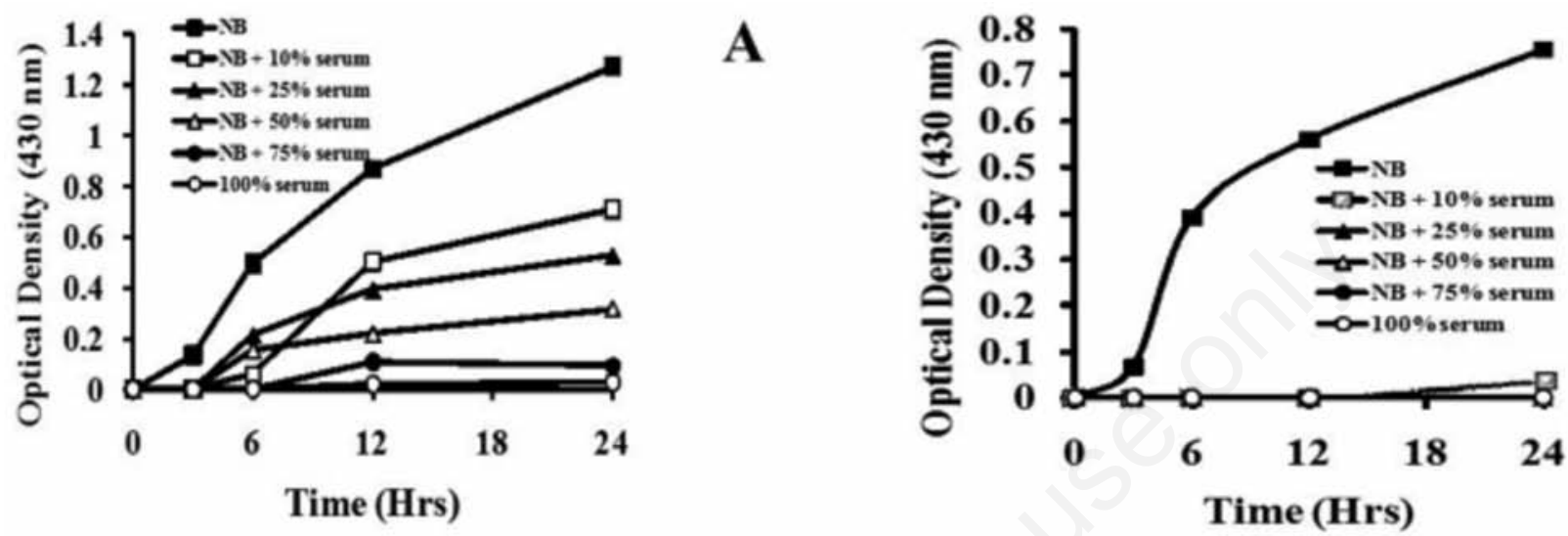

D

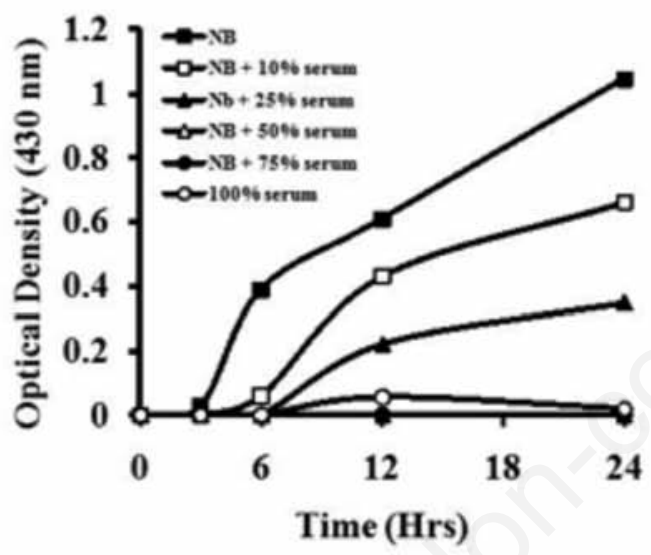

B
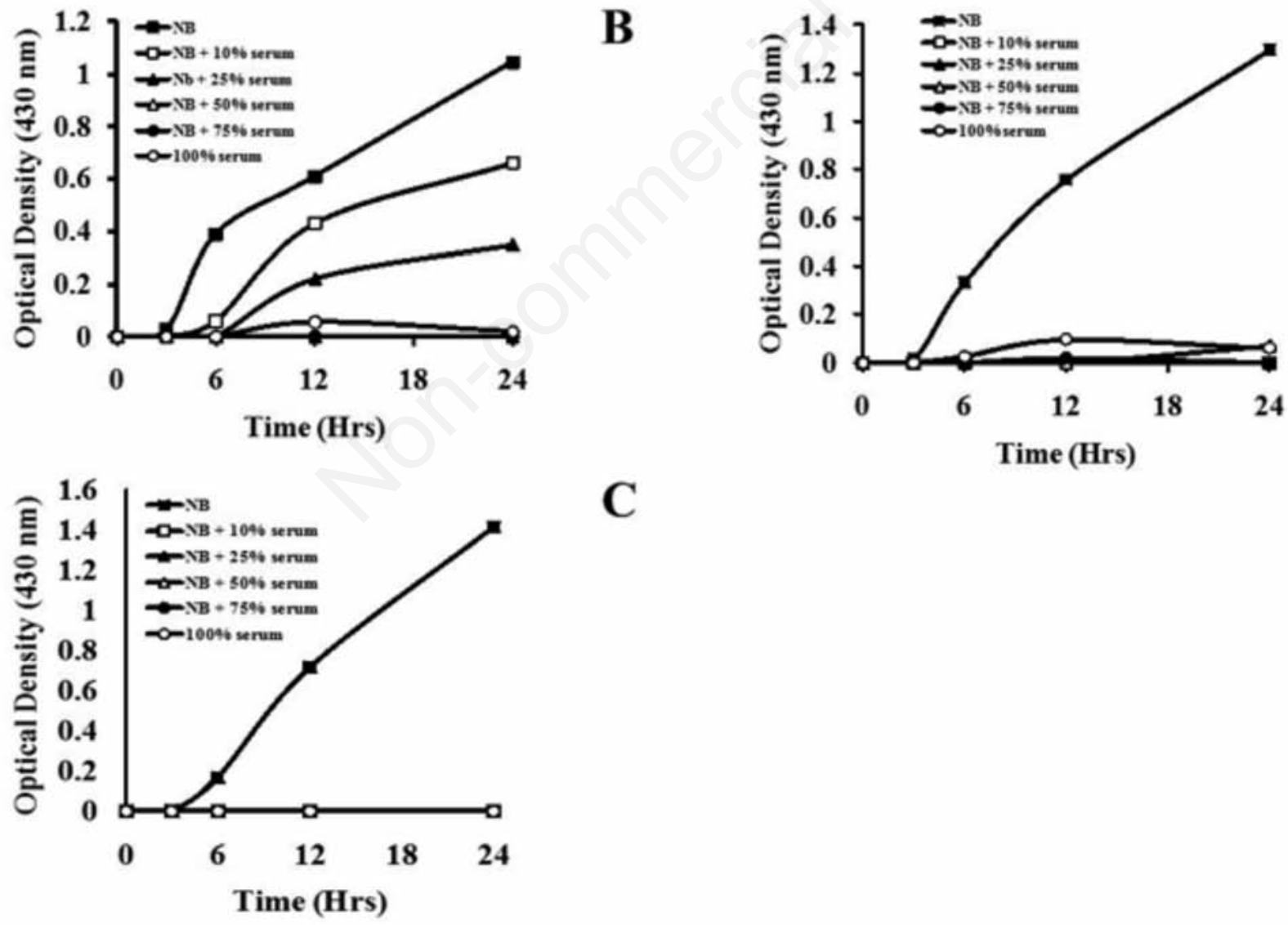

Figure 1. Effects of serum from $V$. komodoensis on growth of Gram negative bacteria. Culture tubes containing $2 \mathrm{~mL}$ of 0 , 10, 25, 50, 75 or $100 \%$ serum from $V$. komodoensis. The cultures were incubated at $37^{\circ} \mathrm{C}$ and their optical densities were measured (430 nm) at 0 , $3,6,12$, and $24 \mathrm{~h}$ post-inoculation. The results are expressed as the means \pm S.D. for four independent determinations. A) Eschericia coliform, B) Klebsiella oxytoca, C) Providencia stuartii, D) Shigella flexneri, E) Salmonella typhimurium. 
54,000 bacteria/ $\mathrm{LL}$. Other reptilians have been shown to exhibit potent antibacterial activities, particularly crocodilian species. Merchant et al..$^{10}$ showed that serum from the American alligator (Alligator missippiensis), when challenged with cultures of $E$. coli as low as $106 / \mathrm{mL}$, could not kill enough bacteria to make a statistical difference in the colony counts, relative to untreated controls cultures. The capacity of alligator serum to kill $E$. coli was approximately 54,000 bacteria/ $\mu \mathrm{L}$. However, the results shown in Figure 3 show that serum from $V$. komodoensis has substantially higher activity than that of Alligator mississippiensis. The serum from $V$. komodoensis showed an approximate 40 -fold increase in the capacity to kill $E$. coli, relative to that of Alligator mississippiensis. The extreme antibacterial properties described in this study could be a result of the evolution of these ancient vertebrates under the conditions of territorial aggression, feeding disputes, challenges for mating rights, etc. Bull et al. ${ }^{11}$ reported that $70 \%$ of the feeding activities of $V$. komodoensis on large prey items occurred with multiple adult animals in close proximity. The broad spectrum of oral bacteria isolated from this species and the high bacterial load of their saliva, ${ }^{4,11}$ would certainly be an issue if bite injuries occurred during territorial battles. Therefore, it is not surprising that these animals could have evolved strong innate immunity defenses to deal with the potential for serious infection due to their aggressive lifestyles. It must be noted that the animals used in this study were captive animals, and thus the immune system could

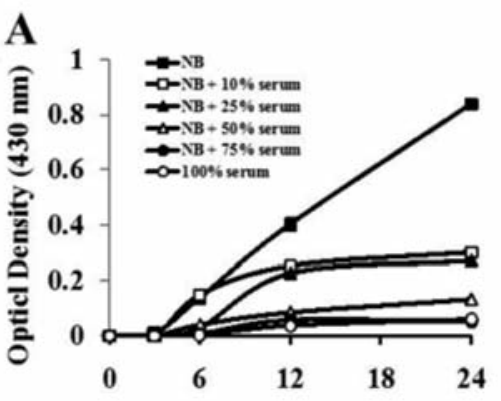

Time (hrs)
B

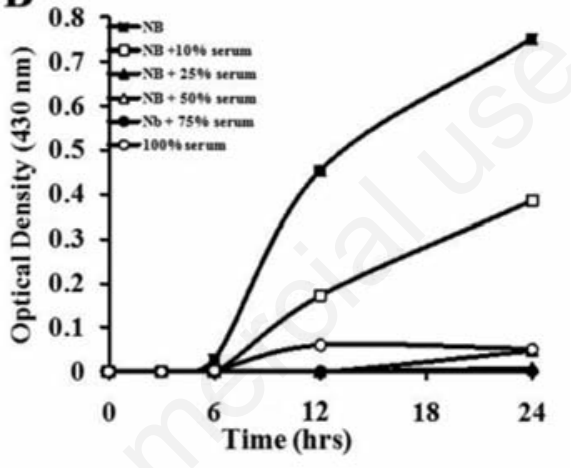

Figure 2. Effects of serum from $V$. komodoensis on growth of Gram positive bacteria. Culture tubes containing $2 \mathrm{~mL}$ of $0,10,25,50,75$ or $100 \%$ serum from Komodo dragons. The cultures were incubated at $37^{\circ} \mathrm{C}$ and their optical densities were measured $(430 \mathrm{~nm})$ at $0,3,6,12$, and $24 \mathrm{~h}$ post-inoculation. The results are expressed as the means \pm S.D. for four independent determinations. A) Staphylococcus aureus, B) Streptococcus epidermitis.

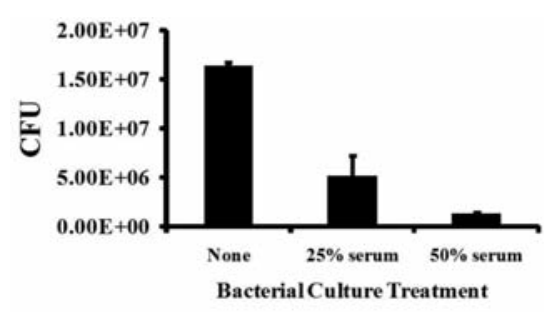

Figure 3. Antibacterial capacity of serum from $V$. komodoensis against $E$. coli. Different concentrations of Komodo dragon serum were incubated with $\mathrm{E}$. coli cultures and plated on nutrient agar. CFUs were determined after overnight incubation at $37^{\circ} \mathrm{C}$. The results are expressed as the means \pm S.D. for four independent determinations.

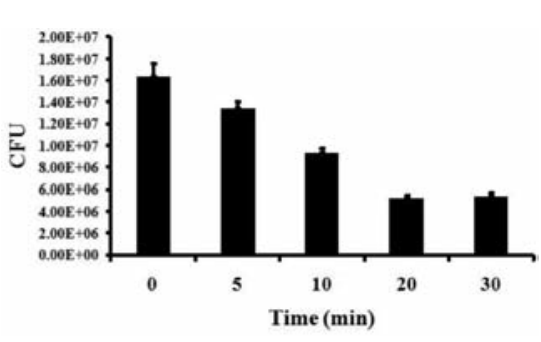

Figure 4. Kinetics of antibacterial activity of serum from $V$. komodoensis against $E$. coli. Cultures of $E$. coli were incubated with $25 \%(\mathrm{v} / \mathrm{v})$ V. komodoensis. Aliquots were removed at various time points and plate on nutrient agar to determine the bacterial survival. The results are expressed as the means \pm S.D. for four independent determinations. potentially be altered by chronic stress of captivity. However, chronic stress typically acts as an immunosuppressive factor in vertebrates, ${ }^{12-17}$ and thus the antibacterial activity of the serum from wild $V$. komodoensis could potentially be underestimated in this study.

The antibacterial effects of Komodo dragon serum is most likely due to an efficient serum complement innate immune-defense. The fact that mild heat treatment $\left(30 \mathrm{~min}\right.$. at $\left.56^{\circ} \mathrm{C}\right)$ almost completely obliterated the observed activities is an indication that serum complement activity is responsible for the antibacterial activities. It has been well-established that serum complement proteins are extremely vulnerable to mild heat treatment, as some of the key proteins components are thermally unstable. ${ }^{18}$ In addition, the antibacterial activity was sensitive to pronase, indicating that at least one of the components required for the observed activity is proteinaceous in nature. This idea is reinforced by the dependence of the antibacterial activities on divalent metal ions (Table 1). It has long been known that divalent metals (magnesium and calcium) are required for mammalian serum complement activity. ${ }^{19-20}$ More recent studies have confirmed the requirement for calcium and magnesium for reptilian serum complement function. ${ }^{21}$ It is not surprising that $V$. komodoensis would have serum complement proteins, as most vertebrate, as well as many ancient invertebrates, exhibit complement activity. ${ }^{22}$ However, the strength with which these proteins kill bacteria is staggering. Before this study, crocodilians were considered to have among the most potent serum complement defense systems. ${ }^{10}$ However, the results in this study show that the potency of Komodo dragon serum complement is much higher than that of crocodilians. ${ }^{23}$ This study represents the first report on innate immune activity of $V$. komodoensis.

\section{References}

1. Ciofi C. The Komodo dragon. Sci Amer 1999;280:85-91.

2. Auffenberg W. The behavioral ecology of the Komodo monitor. Gainesville: University Presses of Florida; 1981.

3. Mertens R. [The family of monitor lizards (Varanidae). Part 1-3: Essays of the Senckenberg Natural History Society]. Die familie der warane (Varanidae). Teil 1-3: Taxonomie. Abhandlungen Senckenbergischen Naturforschenden Gesellschaft. 1942. [Article in German].

4. Montgomery JM., Gillespie D, Sastrawan P, et al. Aerobic salivary bacteria in wild and captive Komodo dragons. J Wildl Dis 2002; 
38:545-51.

5. Pianka ER, King DR. Introduction. In: Pianka ER, King DR, King RA, eds. Varanoid lizards of the world. Bloomington: Indiana University Press; 2004. pp. 3-9.

6. Fry BG, Wroe S, Teeuwisse W, et al. A central role for venom in predation by Varanus komodoensis (Komodo Dragon) and the extinct giant Varanus (Megalania) priscus. Proc Nat Acad Sci USA 2009;106: 8969-74.

7. Farlow J0. Dragons and dinosaurs. Paleobiol 1983;9:207-10.

8. Merchant M, Roche' C, Thibodeaux D, et al. Antibacterial activity of the serum of the American alligator (Alligator mississippiensis). Comp Biochem Physiol B 2003;136:505-13.

9 Siroski P, Pina CI, Larriera A, et al. Antibiotic activity in the plasma of the broad snouted caiman (Caiman latirostris). Zool Stud 2009;49:238-42.

10. Merchant M, Roche' C, Sweeney A, Elsey R. Identification of serum complement activity in the American alligator (Alligator mississippiensis). Comp Biochem Physiol B 2005;141:281-8.

11. Bull JJ, Jessop TS, Whiteley M. Deadly drool: evolutionary and ecological basis of septic bacteria in Komodo dragon mouths. PLoS One 2010;5:e11097.

12. Berczi I. The stress concept and neuroimmunoregulation in modern biology. Ann NY Acad Sci 1998;851:3-12.

13. Dohms JE, Metz A. Stress-mechanisms of immunosuppression. Vet Immunol Immunopathol 1991;30:89-109.

14. Glaser R., Kiecolt-Glaser JK, Malarkey WB, Sheridan JF. The influence of psychological stress on the immune response to vaccines. Ann NY Acad Sci 1998;840:649-55.

15. Magnusson U, Wattrang E, Tsuma V, Fossum C. Effects of stress resulting from short-term restraint on in vitro functional capacity of leukocytes obtained from pigs. Amer J Vet Res 1998;59:421-5.

16. Sheridan JF, Dobbs C, Jung J, et al. Stressinduced neuroendocrine modulation of viral pathogenesis and immunity. Ann NY Acad Sci 1998;840:803-8.

17. Shini S, Huff GR, Shini A, Kaiser P. Understanding stress-induced immunosuppression: Exploration of cytokine and chemokine gene profiles in chicken peripheral leukocytes. Poul Sci 2010;89: 841-51.

18. Seifter S, Pillemer L, Ecker EE. Immunochemical studies on human serum: II. In vitro studies on the stability of human complement and its components. J Immunol 1943;47:195-204.

19. Levine L, Cowan KM, Osler AG, Mayer MM. The role of calcium and magnesium ions in complement fixation and immune hemolysis. I: uptake of complement nitrogen by specific precipitates and its inhibition by ethylenediaminetetraacetate. J Immunol 1953;71:359-66.

20. Levine L, Osler AG, Mayer MM. The role of calcium and magnesium ions in complement fixation and immune hemolysis: III. The respective roles of calcium and magnesium ions in immune hemolysis. $\mathrm{J}$ Immunol 1953;71:374-9.

21. Merchant M, Verret B, Elsey RM. Role of divalent metal ions in serum complement activity of the American alligator (Alligator mississippiensis). Comp Biochem Physiol B 2005;141:289-93.

22. Sunyer 0, Lambris J. Evolution and diversity of the complement system of poikilothermic vertebrates. Immunol Rev 1998; 166:39-57.

23. Merchant $\mathrm{M}$, Mills $\mathrm{K}$, Leger $\mathrm{N}$, et al. Comparison of innate immune activity of all 23 known living crocodilian species. Comp Biochem Physiol B 2006;143:133-7. 